\title{
Tomasz Wiślicz
}

twislicz@ihpan.edu.pl

Instytut Historii im. Tadeusza Manteuffla PAN

\section{FABRYKACJA NIERZĄDNICY, \\ CZYLI O OFIARACH WZGLĘDNEJ SWOBODY SEKSUALNEJ NA POLSKIEJ WSI PRZEDROZBIOROWEJ}

\author{
The Fabrication of a Harlot, or, The Victims of a Relative \\ Sexual Freedom in the Polish Village in Prepartition Times
}

\begin{abstract}
Streszczenie. We wcześniejszych publikacjach opisałem względną swobodę seksualną na polskiej wsi w okresie przedrozbiorowym, dotyczącą przede wszystkim stosunków przedmałżeńskich, do których chłopska społeczność odnosiła się z pobłażliwością graniczącą z przyzwoleniem tak długo, jak długo nie dochodziło do spłodzenia dziecka. W takim wypadku, zgodnie z zasadą „podwójnego standardu", odpowiedzialność ponosiła głównie kobieta, jednak preferowanym przez opinię publiczną rozwiązaniem była legalizacja związku przez małżeństwo, a gromada potrafiła zmusić wahających się mężczyzn do ślubu. W sumie skutkowało to pewnym optymizmem kobiet rozpoczynających przedmałżeńskie współżycie seksualne. Niemniej pojawiały się również ofiary tego systemu, które na skutek swojego życia seksualnego wyrzucane były na margines lub w ogóle usuwane ze wspólnoty. Oczywiście były to niemal wyłącznie kobiety, ale bliższa analiza wskazuje, że w ich przypadku dochodziło do krzyżowania się dyskryminacji ze względu na płeć z dyskryminacją klasową. Celem artykułu jest ukazanie, w jaki sposób społeczność wiejska budowała ich obraz jako „nierządnic”, żeby uzasadnić ich marginalizację lub eliminację. Nie chodzi tu wyłącznie o fabrykację dyskursywną, ale również o rzeczywiste działania, których rezultatem była seksualna stygmatyzacja niektórych kobiet o upośledzonej pozycji społecznej, prowadząca do ulokowania ich w kategoriach „nierządnej”, „zawitki” (panny z dzieckiem) lub „dzieci tracącej” (dzieciobójczyni).
\end{abstract}

Słowa kluczowe: intersekcjonalność; wieś przednowoczesna; zaloty; seks przedmałżeński; urodzenia nieślubne; margines społeczny wsi.

Abstract. In my earlier publications, I have described a relative sexual freedom in the Polish village in the prepartition period. It mostly applied to premarital intercourse to which rural community approached with certain acceptance, as long as no child was conceived. If it was, it was mostly the woman who was held responsible as a result of the "double standard". However, the solution preferred by the public opinion was legalizing the relationship via marriage and rural courts could compel hesitant men to marry. Still, it resulted in some kind of optimism expressed by women who engaged in premarital sex. Nevertheless, there were also victims of the system, who, in consequence 
of their sexual practices, were thrown to the margins of their society or even were completely excluded from it. Obviously, those were almost exclusively women, but closer analysis shows that in their case, gender-based discrimination and class discrimination intersected. The goal of this article is to show the way in which the village society build their image of 'harlots' to justify their marginalization or exclusion. It was not only about the discursive fabrication but it also entailed real actions, the result of which was sexual stigmatization of some women of low social status, leading to their placement in categories such as 'harlot', 'bastard's mother' or 'infant killer'.

Keywords: intersectionality; premodern village; courtship; premarital sex; illegitimate births; village poor.

W książce Upodobanie. Małżeństwo i związi nieformalne na wsi polskiej XVII-XVIII wieku. Wyobrażenia społeczne i jednostkowe doświadczenia (Wiślicz 2012; zob. też Wiślicz 2017) opisałem względną swobodę seksualną na polskiej wsi w okresie przedrozbiorowym, dotyczącą przede wszystkim stosunków przedmałżeńskich, do których chłopska społeczność odnosiła się z pobłażliwością graniczącą z przyzwoleniem, jednak pod warunkiem zachowania pewnych zasad. W modelu tym najważniejszym okresem kształtowania się form życia osobistego kobiet i mężczyzn na wsi był okres „młodości", czyli od osiągnięcia dojrzałości płciowej do przeciętnego wieku zawierania małżeństw, który wynosił 20-24 lata dla kobiet i 25-29 lat dla mężczyzn (Kuklo 2009: 279-280). Niezależnie od tego, czy młodzi ludzie spędzali ten okres na służbie w obcych gospodarstwach chłopskich, czy też w gospodarstwie rodziców, mieli możliwość dość swobodnego spotykania się z osobami przeciwnej płci i wchodzenia w krótkotrwałe bądź dłuższe związki. Sprzyjały temu zarówno codzienna, wspólna praca, jak i święta religijne, jarmarki czy zabawy w wiejskiej karczmie. Społeczność wiejska odnosiła się ze sporą pobłażliwością do stosunków przedmałżeńskich tak długo, jak zachowana była zasada dyskrecji zarówno jeśli chodzi o słowa, jak i o czyny. Starano się takich stosunków po prostu nie dostrzegać. Pobłażliwość ta wynikała zresztą z osobistych doświadczeń - młodzi powtarzali bowiem zachowania rodziców, a próby wprowadzenia przez Kościół surowszej oceny moralnej tzw. wszeteczeństwa (łac. fornicatio, czyli stosunków seksualnych osób stanu wolnego) nie spotykały się ze zrozumieniem w środowisku chłopskim. Dopiero w połowie XVIII wieku dały się zauważyć pierwsze oznaki zmian w chłopskiej ocenie moralnej stosunków przedślubnych.

W ustępującym modelu stosunków takich nie dostrzegano, dopóki nie doszło do spłodzenia dziecka. W tym momencie dopiero opinia wiejska stwierdzała, że doszło 
do „przestąpienia bożego przykazania”, a obydwojgu kochankom groziło ukaranie fizyczne i grzywny, a niekiedy i pokuta publiczna. Oboje też ponosili uszczerbek na opinii, szczególnie dotkliwy w przypadku kobiet, jednak rzadko prowadzący do wypadnięcia na margines społeczności wiejskiej. Działo się tak dlatego, że jeśli kobieta zaszła w ciążę w wyniku współżycia z mężczyzną stanu wolnego, to oczekiwanym rozwiązaniem była legalizacja związku - zawarcie małżeństwa. Wiejska opinia publiczna preferowała takie rozwiązanie, a wahających się potrafiła zmusić do ślubu (nierzadko wyrokiem sądu gromadzkiego). Takie rozwiązanie było możliwe również dlatego, że w warunkach wsi pańszczyźnianej wielkość dziedziczonego majątku nie miała zasadniczego znaczenia przy kojarzeniu chłopskich małżeństw (wydzielenie ziemi uprawnej i dostarczenie narzędzi rolniczych leżało bowiem w interesie dworu), natomiast liczyły się kryteria subiektywne, takie jak zdrowie, pracowitość czy gospodarność. Badania demograficzne wskazują, że w różnych rejonach Polski w XVII-XVIII wieku od 10\% do 30\% panien młodych na wsi stawało na ślubnym kobiercu będąc w ciąży (Kuklo 2009: 349-350). Dane te można uznać za miarę popularności metody unikania kłopotów przez zawarcie małżeństwa, ale mogą one obejmować także przypadki, gdy za decyzją o ślubie następowało podjęcie współżycia przez przyszłych małżonków, bez oczekiwania na dopełnienie ceremonii.

Model ten skutkował pewnym optymizmem osób rozpoczynających „niezalegalizowane" współżycie seksualne. Można było bowiem zakładać, że jeśli w jego rezultacie doszłoby do spłodzenia dziecka (pomimo stosowania różnych praktyk i środków antykoncepcyjnych, zwykle mało skutecznych), to uda się uniknąć konsekwencji prawnych oraz utraty dobrej opinii po prostu legalizując związek. Wystarczyło dobierać kochanka lub kochankę spośród grupy osób, z którymi potencjalnie można było wziąć ślub (to znaczy nie było przeszkód prawnych lub społecznych do zawarcia związku małżeńskiego).

Oczywiście model ten obciążony był pewnym ryzykiem, gdyż nie zawsze spłodzenie potomka w związku przedmałżeńskim prowadziło do ślubu. W takich wypadku, zgodnie ze sformułowaną jeszcze przez Keitha Thomasa zasadą "podwójnego standardu", odpowiedzialność ponosiła głównie kobieta (Thomas 1959; zob. też Walker 1996 i Capp 1999). Wprawdzie sądy gromadzkie zmuszały kawalerów, którzy nie chcieli lub nie mogli się ożenić z matką swojego dziecka, do świadczeń alimentacyjnych, ale tylko kobieta traciła pozycję na rynku matrymonialnym wsi lub w ogóle z niego wypadała. 
Poniższe rozważania chciałbym poświęcić ofiarom systemu owej względnej swobody seksualnej ludzi stanu wolnego na wsi polskiej, ofiarom, które z punktu widzenia przekazów źródłowych są raczej marginalne, ale być może wrażenie to wynika z faktu, że zostały przez system na margines wyrzucone. Pożyteczną dla mojej analizy będzie kategoria intersekcjonalności, która wskazuje, że w ich wypadku dochodziło do krzyżowania się dyskryminacji ze względu na płeć z dyskryminacją ze względu na status społeczny. Intersekcjonalność w ciągu ostatnich lat stała się przedmiotem ożywionej dyskusji oraz licznych ujęć teoretycznych (spośród których najbardziej inspirujące to: Taylor 2010; Anthias 2013; Anthias 2014), znajduje też liczne zastosowania w naukach społecznych. Zdecydowanie rzadziej korzysta się z niej w naukach historycznych, zwłaszcza w odniesieniu do dawniejszych epok. W przypadku badań nad krzyżowaniem się problemów płci i klasy na wsi przednowoczesnej w Rzeczypospolitej nie dysponujemy jeszcze żadnymi opracowaniami tematu. Za pionierski można uznać przyczynek Andrzeja Wyczańskiego (2005), a poza tym można wymienić nieliczne opracowania dotyczące zróżnicowania społecznego ludności chłopskiej (Baranowski 1986; Kopczyński 1995; Kamler 2005; Jawor 2010; Guzowski 2012) lub położenia kobiety wiejskiej (Guzowski 2011; Kołacz-Chmiel 2013) i jej seksualności (Wiślicz 2012; Vinnychenko 2013; Bilous 2015; Harasymchuk 2015). Mniejsze znaczenie posiadają opracowania etnologiczne, przede wszystkim dlatego, że dotyczą one niemal wyłącznie okresu pouwłaszczeniowego na wsi polskiej, a więc epoki pod względem społecznym zupełnie odmiennej od wczesnej nowożytności. Towarzyszące im założenie niezmienności kultury chłopskiej, zwłaszcza w przypadku stosunków rodzinnych i obyczajowości seksualnej zostało sformułowane na wyrost, czego dowodzi analiza źródeł historycznych. Inną sprawą jest brak wiarygodnych badań etnologicznych na temat seksualności ludu, co wynikało ze społecznych i kulturowych uwarunkowań ludoznawstwa w XIX wieku (zob. np. Libera 1995: 145-147). Ciekawe analizy tego tematu przynoszą dopiero opracowania Ludwika Stommy (1975) i Ryszarda Tomickiego (1977) z lat 70. XX wieku i późniejsze Dobrosławy Wężowicz-Ziółkowskiej (1991a, 1991b, 2008) oraz Andrzeja Perzanowskiego (2009, zwłaszcza 75-79).

Celem tego artykułu jest ukazanie, w jaki sposób społeczność wiejska budowała seksualnie stygmatyzujący obraz kobiet o upośledzonej pozycji społecznej, żeby uzasadnić ich marginalizację lub eliminację poprzez przypisanie do kategorii „nierządnych”, „zawitek” (panien z dzieckiem) lub „dzieci tracących” (dzieciobójczyń). 
Podstawą źródłową są akta sądów wiejskich oraz wybrane sprawy rozstrzygane przez sądy miast, o ile dotyczyły chłopów i chłopek. Szczególnie interesujące dla mojej analizy są procesy o wszeteczeństwo (fornicatio), wynikłe zwykle z dochodzenia w sprawie narodzin dziecka nieślubnego, oraz procesy o dzieciobójstwo, w których relacjonowana jest często „seksualna historia” sądzonej. Podstawa źródłowa analizy obejmuje łącznie ponad 400 zapisów sądowych z XVII-XVIII wieku, głównie z terenów Małopolski i Rusi Czerwonej, lecz również Wielkopolski, Mazowsza i Ziemi Chełmińskiej(zasięg geograficzny badań uzależniony jest od stanu zachowania archiwaliów).

Zacznijmy od sytuacji, do której dość często dochodziło w sądach wiejskich: opisywany powyżej model względnej swobody seksualnej osób stanu wolnego nie zadziałał bezkonfliktowo i sprawa wypełnienia przez mężczyznę zobowiązań wobec kobiety w przypadku zajścia przez nią w ciążę stawała się przedmiotem interwencji władz. Nierzadko kobiety skarżyły wprost o niedotrzymanie ustnego zobowiązania do małżeństwa: „namawiając na eksces, obiecował się z nią żenić i na tym fundamencie Pana Boga obrażali" (Vetulani 1962-1963: nr 868 [1753]). W wielu przypadkach interwencja sądu, postraszenie karą cielesną i finansową były wystarczającą zachętą dla mężczyzn, żeby słowa dotrzymali. Wśród zarejestrowanych w księgach gromadzkich Kasiny Wielkiej (pow. limanowski) w latach 1602-1714 wyroków w sprawie nierządu między osobami wolnymi ponad $29 \%$ zakończyło się dobrowolnym lub nakazanym przez sąd ślubem podsądnych ${ }^{1}$. W kresie muszyńskim (czyli rozległych dobrach biskupstwa krakowskiego wokół Muszyny) w latach 1754-1766 odsetek ten sięgał blisko $43 \%^{2}$. W pozostałych przypadkach jednak domniemani ojcowie uchylali się od poślubienia kochanek lub wręcz negowali swoje ojcostwo. Nie wdając się na razie w rozważania na temat faktycznych powodów ich stanowiska w tej kwestii, przyjrzyjmy się sposobom, w jaki konstruowali przed sądem obraz tych kobiet, które obwiniały ich o spowodowanie ciąży.

Po pierwsze, wskazywali na kobiece sprawstwo: „przyznał się być winnym do wszystkiego, ale tylko raz szczególny i lubo go sama tentowała do grzechu nie chciał więcej” (BNLUN 512/III: 46 [1734]); „sama go o to napastowała i w łóżko do niego sama przyszła” (APT, ASD 4: 5v [1747]); „sama była ponętą do grzechu popełnionego i sama do niego chodziła" (APT, ASD 6: 107v [1755]) etc. Nie chodzi tu tylko o przypisanie

\footnotetext{
${ }^{1}$ Obliczenia własne na podstawie edycji Bolesława Ulanowskiego (1921).

${ }^{2}$ Obliczenia własne na podstawie: ANK, dep. rkps 100-101.
} 
choćby części winy kobiecie, ale też o stworzenie obrazu byłej kochanki jako kobiety aktywnej seksualnie w sposób wykraczający poza jej domyślny „stan dziewiczy”. Wyjaśnić tu należy, że dziewictwo nie było jeszcze wówczas na wsi utożsamiane ze stanem błony dziewiczej, ale zasada dyskrecji widziała w niezamężnej kobiecie istotę raczej pasywną seksualnie (Wiślicz 2017). Dziewczęta, które zaszły w ciążę jako panny, podkreślały swoją całkowitą ignorancję w sprawach seksu i jeśliby wierzyć ich zeznaniom, zachodziły w ciążę w wyniku pojedynczego stosunku, najlepiej jeszcze w jakiś sposób wymuszonego przez chłopaka - namową, podstępem lub nawet przemocą (por. Tóth 1989: 45). Zatem podkreślanie przez mężczyznę inicjatywy w sprawach seksu ze strony niezamężnej kobiety miało na celu podważenie jej wiarygodności w ramach stereotypowych ról płciowych.

Podobny cel miało sugerowanie, że kobieta miała wielu partnerów seksualnych: „Michalcziczia żałowała się na sługę Marczina Dudka, Piotra, że z nim płodem zastąpiła. A on się do tego nie znał, mówiąc, że pierwej powiedała na mego swaka i na insze"3 (BJ 122: 3v [1587]). Pewna Jagnieszka, którą podobno Stanisław Owczarczyk „obrzemienił”: „chodząc na jarmark do Radzynia z żołnierzami do karczmy chodziła i z nimi tańcowała, z których jeden dał jej zł. 2 aby mu była powolną do grzechu" (APT, ASD 1: 425 [1732]). Zderzenie dwóch strategii prezentacji przed sądem aktywności seksualnej kobiety najlepiej widoczne jest w sprawie z 1725 r. z Kokocka (pow. chełmiński), gdzie Jan Krol zeznał, że „raz tylko z Maryanną Walowną miał uczynek cielesny, i to podpiło[...], lecz ta Maryanna z różnemi się łącząc brzemienną z kim innym została”. Marianna zaś twierdziła, że „z Janem tylko raz miała i zaraz zapadła, a z nikim innym prócz niego nie miała, a i nawet tego jednego razu przymuszona była" (APT, ASD 1: 324-325 [1725]).

Jeśli nie dało się pomówić kobiety o rozwiązłość seksualną, to przynajmniej należało zasugerować jej zbyteczną skłonność do zabawy, czego oznaką miało być nadużywanie alkoholu:

[Katarzyna Zagasiowna] gorzałkę piła czyli w Nowej Górze u Czechowica, czyli na Miękinie u Lisonia, tylko że jej ludzie dawali pić częstując ją, kędy tam był i Paweł Kłeczek, i poczęstował ją, i bawiła się do samego wieczora [...] Także powtóre przed św. Janem czyli po św. Janie była w Nowej Górze i podpiła sobie, i on tamże był w Nowej Górze aż do wieczora, która w nocy z nim także podpiłym idąc, aż przyszedłszy

\footnotetext{
${ }^{3}$ „Michalczyca skarżyła się na sługę Marcina Dudka, Piotra, że zaszła z nim w ciążę. A on się do tego nie przyznawał, mówiąc, że wcześniej skarżyła o to mojego szwagra (męża siostry) i innych".
} 
do Filipowic minąwszy Kłeczkową chałupę ku swojej idąc alias ku ślusarzowej tamże na nawsiu ten grzech popełnili (ANK, IT 229h: 16-17 [1751]).

Najbardziej kompletny obraz wiejskiej nierządnicy sporządził ksiądz Stanisław Leliwa Cichorski, pleban w Graboszewie pod Słupcą, opisując matkę dziecka, które przyniesiono mu do ochrzczenia: „to niecnotliwa była niewiasta, bezecnie żyjąc, postów nie obserwowała, posty łamiąc co mogła kradła, gachów sobie korumpując, w domu sypiać nie chciała, tylko po nocy chodziła" (APP, Akta m. Słupcy I/5: 10 [1727]).

Tak oto wyłania się nam obraz wiejskiej kobiety, do której nie stosowano zasady zabezpieczającej aktywność seksualną młodych ludzi stanu wolnego na wsi poprzez moralny i administracyjny przymus małżeństwa w przypadku zajścia dziewczyny w ciążę. Jest to kobieta „wszeteczna”: aktywna seksualnie, inicjująca współżycie, posiadająca wielu kochanków, lubiąca zabawę i alkohol, a w rezultacie skłonna i do innych grzechów, do łamania postów i kradzieży. Można by widzieć w niej słabo widoczną w źródłach hipotetyczną wiejską prostytutkę (por. Wiener 1975: 42; Karras 1996: 24-25; Sikorska-Kulesza 2004: 222; Scott 2016: 76-77), sprawa jest jednak bardziej skomplikowana.

Przyjrzyjmy się rzeczywistym powodom, dla których niektórzy wiejscy kawalerowie nie chcieli wypełnić kulturowego zobowiązania do poślubienia kobiet, które zaszły z nimi w ciążę. Pierwszym były przeszkody prawne - kochankowie byli spokrewnieni lub spowinowaceni w stopniu wymagającym starania się o kościelną dyspensę. Nie była to wszakże sprawa nie do załatwienia, a biorąc pod uwagę endogamię gromad chłopskich, staranie się o dyspensę nie mogło być czymś wyjątkowym przy planowaniu małżeństwa na wsi (Kuklo 2009: 291-294). Znacznie poważniejszą przeszkodą było zróżnicowanie społeczne wsi. Wprawdzie struktura społeczna wsi pańszczyźnianej była poważnie spłaszczona ze względu na ograniczenie praw do ziemi uprawnej oraz utrudniony dostęp do miejskich rynków, ale to nie znaczy, że nie pielęgnowano lokalnych hierarchii. Model względnej swobody seksualnej młodych ludzi, którzy w każdej chwili mogą wziąć ślub, dotyczył dzieci osiadłych członków gromady: wiejskich rzemieślników, kmieci, zagrodników, może także chałupników. Poza systemem znajdowali się różni „przychodnie”, sezonowi robotnicy, luźni, zawodowa służba, komornicy. Najlepiej widać to w przy padku służących. Owszem, część córek gospodarzy również służyła w ramach tzw. life-cycle service, czyli charakterystycznej dla wczesnonowożytnego modelu rodziny na północy Europy okresowej służby młodych ludzi w obcych gospodarstwach, zwykle w tej samej wsi. 
Ich pozycja w obcym gospodarstwie czy wręcz bezpieczeństwo zależały od osadzenia ich rodziny w strukturze wsi, od ich ojców i braci. Nie mogło to uchronić ich od zajścia w ciążę z innym służącym czy z synem gospodarza, ale zapewniało dobrą pozycję negocjacyjną w przypadku niechęci kochanka do formalizacji związku. Co innego w przypadku służących, których status był dziedziczny, albo przybyłych „ze świata” w poszukiwaniu pracy. Ich ciała należały do gospodarza lub jego synów, czasem - jak się zdaje - za cichym przyzwoleniem gospodyni (por. Karpiński 1992: 53; Barber 1993; Gowing 2003: 60). Wedle opowieści Barbary Staząnki, służącej u Sebastiana Januszkowica w Czukwi (rejon samborski obwodu lwowskiego):

W wielkanocny poniedziałek poszła żona jego do rodzica swego, a mnie kazała abym jej dozierała dziecięcia. Sam leżał na nalepie i tak on porwawszy się poszedł na dwór wyszedłszy wołał mnie do siebie, jam nie chciała pójść do niego tedy on przyszedł do mnie i co mu się podobało uczynił mi. Drugi raz, także poszła na różaniec, a mnie dziecinę dała piastować i kazała mi, abym tę dziecinę odniosła, a męża jej obudziła, jam dziecinę przyniosła, on spał na ziemi i porwał mnie za podołki wywrócił, co chciał ze mną czynil, i od tego razu zostałam z nim praegnans (CPAHUL 142/1/2: 490-491 [1678]).

A kiedy Barbarze urósł brzuch, gospodyni namawiała ją, żeby o spłodzenie dziecka obwiniła nieżyjącego już Mikołaja Greliszaka. Zdarzało się w prawdzie, że służąca zaciągnęła do ołtarza gospodarskiego syna lub nawet gospodarza-wdowca, lecz były to sytuacje wyjątkowe. Zwykle mogła liczyć co najwyżej na jakieś drobne gratyfikacje: „deklarował trzewiki żółte, ale nie kupił, tylko pierścionek żółty mosiężny i groszy sześć dał" (jak zeznawała Marunka z Kobła na Samborszczyźnie, zob. CPAHUL 856/1/172: 1[1757]).

Wydaje się, że na wsi mieszkały całe grupy kobiet o statusie służących lub komornic, które prowadziły życie seksualne, rodziły dzieci, a nie miały żadnej możliwości zawarcia legalnego małżeństwa. Ustawa dla dóbr łąckich (pow. nowosądecki) z 1702 r. mówi o nich:

Na te niewiasty, które cielesnego się grzechu dopuszczają i potomstwa dostają, a mężów nie mają, prawo dekretuje, aby za ten uczynek publicznie w gromadzie rózgami stą plag chłostane były, a jeżeliby się nie upamiętały i na podobny grzech znowu zezwalały, takowąż plagą i wygnaniem z państwa karane być mają, a gospodarz, u którego by się to w domu stało, dziesięć grzywien do dworu, pięć funtów wosku do kościoła farnego i plag trzydzieści; podobnymi plagami i gospodynie za niedozór w domach swoich karane być mają, gdyż się przez ten nierząd i ciężka obraza boska - ściągająca pokaranie na całe 
poddaństwo - dzieje [...](Vetulani 1962-1963: nr 599 [1702]; por. nr 544 [1670] i 603 [1712];

Ulanowski 1921: nr 7403 [1672]).

Recydywistkom ustawa groziła wygnaniem, czyli najprawdopodobniej wyświeceniem, tj. rytualnym wypędzeniem ze wsi. W zachowanych aktach sądu dóbr łąckich nie mamy jednak żadnych dowodów, że rzeczywiście tę karę zastosowano. Trudno się zgodzić z Bohdanem Baranowskim, który twierdził, że opinia wiejska odnosiła się do „upadłej” kobiety „z nieukrywaną nienawiścią”, zaś zwyczaj nakazywał jak najbardziej hańbiące wygnanie jej ze wsi (Baranowski 1970: 271). Ze źródeł wynika, że karę wyświecenia za przestępstwa obyczajowe stosowano tylko wyjątkowo i to głównie w dobrach kościelnych. W należącej do krakowskich dominikanów Kasinie Wielkiej w latach 1602-1714 ledwie co piąty wyrok (z 41 zarejestrowanych) w sprawach przestępstw seksualnych dekretował, aby wygnać oskarżoną. Kara ta spotykała zasadniczo recydywistki, kazirodczynie i kobiety związane ze środowiskiem przestępczym. Sądy kasińskie były i tak wyjątkowo surowe. W okresie 1754-1766 sąd kresu muszyńskiego (własności biskupów krakowskich) tylko jednej „nierządnicy” kazał opuścić wieś, i to prawdopodobnie darując jej bolesną otoczkę rytualną wyświecenia.

Co zatem działo się z kobietami, które rodziły nieślubne dzieci i pozostawały we wsi? Przede wszystkim trzeba zauważyć, że skala zjawiska nie była zbyt duża narodziny nieślubnych dzieci na wsi polskiej zdarzały się dość rzadko. Wyrywkowe badania, głównie dla XVIII wieku pokazują, że w parafiach wiejskich rodziło się od 1\% do 7\% dzieci nieślubnych (Kracik 1977: 207-208; Górna 2001: 5-36; Kuklo 2009: 386; Wyżga 2010: 158; Ryguła 2016: 15). Ponadto nie wszystkie matki nieślubnych dzieci traciły szanse na rynku matrymonialnym: w parafii Krapkowice (na Opolszczyźnie) w drugiej połowie XVIII wieku 21\% kobiet, które urodziły nieślubne dziecko, stawało na ślubnym kobiercu, z czego 2/3 w ciągu roku od jego urodzin (Górna 2001: 39), natomiast w Krasnem na Podkarpaciu (pow. rzeszowski) w latach 1786-1863 co trzecia panna z dzieckiem wychodziła w końcu za mąż (Rejman 2006: 24-25). Z badań etnograficznych na Podhalu wynika, że w XIX w. urodzenie nieślubnego dziecka mogło nawet zwiększać atrakcyjność matrymonialną panny, gdyż w ten sposób udowadniała swoją płodność, a dziecko po odchowaniu stawało się dodatkową siłą roboczą w gospodarstwie (Kowalska-Lewicka 1967: 234-238; Kowalska-Lewicka 1971).

Jeśli jednak ojciec dziecka nie zdecydował się na poślubienie swojej kochanki, to mogła ona liczyć na alimenty. Niezależnie od moralnej oceny jej „prowadzenia się", sądy skazywały sprawcę ciąży na zaopatrzenie kobiety w środki na odchowanie 
noworodka: czasem była to jakaś gotówka, a prawie zawsze - krowa mleczna. Aż do początków XVIII wieku sądy wiejskie - wbrew stanowisku Kościoła - w ogóle nie zajmowały się kwestią winy kobiety za wszeteczeństwo. Dopiero potem zaczęły uznawać kobiety za współwinne i wymierzać kary (głównie fizyczne). Nie przestały jednak zasądzać alimentów na ich korzyść (szerzej: Wiślicz 2012: 81).

Ciężarna panna jeszcze przed urodzeniem dziecka powinna się „zaczepić” albo „zawić”, czyli przywdziać nakrycie głowy, gdyż od tej pory nie wypadało jej pokazywać się z gołą głową lub w wieńcu - tak jak pannom (Ciszewski 1927: 19-20). Zawicie było publicznym uznaniem utraty panieństwa, porównywalnym do oczepin w rytuale weselnym, ale - oczywiście - niehonorowym, dlatego też zwlekano z nim jak najdłużej, jeśli pozostawały jakiekolwiek nadzieje na ślub ze sprawcą ciąży lub z innym mężczyzną (AGAD, ZBS 409/523: 283 [1799]). Od określenia „zawić się”, powstało słowo „zawitka”, czyli „panna z dzieckiem”. W wykorzystanych źródłach historycznych nie udało się odnaleźć żadnego innego wśród ponad 30 gwarowych określeń synonimicznych, zebranych przez Mieczysława Szymczaka (1968).

Zawitka stawała się jakby kobietą drugiej kategorii, jeśli chodzi o postrzeganie jej seksualności. Z zasady uważano ją za osobę o „obniżonej” moralności, co znajdowało swój wyraz nawet w decyzjach władz administracyjnych, na przykład w dekrecie sądu dworskiego klucza bratkowickiego (pow. rzeszowski) z 1732 r., który łagodnie potraktował cudzołóstwo Mikołaja Dziuby, gdyż „się to stało nie z panną, ani z mężatką, ale z zawitką" (AGAD, AR Dzierżawa Bratkowice 4: CLXIV/126[1732]; por. Rolle 1869: 315).

„Moralnie podejrzane” stawały się również wdowy „w wieku reprodukcyjnym", jeśli nie znalazły sobie męża w zwyczajowym czasie, czyli około roku po owdowieniu, w którym to czasie powtórnie za mąż wychodziło 65\% wdów (dane te dotyczą parafii Szaradowo na Pałukach, zob. Górny 1996: 82-83). Ten wysoki procent wynikał $\mathrm{z}$ faktu, że do prowadzenia gospodarstwa z czysto ekonomicznych względów konieczne było posiadanie współmałżonka. Jeśli wdowa nie znalazła nowego męża, to szybko następował proces jej pauperyzacji, wypadała na margines wsi i ostatecznie traciła szansę na powtórne zamążpójście. Wdowy uznawano za osoby uświadomione seksualnie, więc jeśli zachodziły w ciążę, to ponosiły większą odpowiedzialność za swoje czyny, czemu dał wyraz sąd wsi Czukwi, uzasadniając wyrok chłosty na Anastazję Pyskaczkę: „ona bywszy wdową wiedziała wszystko, 
jeszcze inszych powinna nauczyć, a [...] się odważyła na to" (CPAHUL 142/1/8: 27 (od tyłu) [1776]; por. Ulanowski 1921, nr 4019 [1744]).

Problem z wdowami polegał na tym, że funkcjonowały na obrzeżach wiejskiego rynku matrymonialnego i formalnie mogły starać się o tych samych mężczyzn, co panny. Tyle że w przypadku zajścia w ciążę z kawalerem miały znacznie mniejsze szanse niż panny na namówienie go lub zmuszenie do ożenku. Sposób, w jaki postrzegano ich reputację, powodował, że gromada nie stawała po ich stronie w przypadku kontrowersji, co jednocześnie sprzyjało ich wykorzystywaniu seksualnemu przez mężczyzn. Tak było w przypadku Hasi Tuledzyny, wdowy, którą emablował niejaki Senko:

Za mną chodził, zwodził mnie, ja po wodę on za węgły, jam po drwa, on za wiaty, jam mu mówiła: „czego ty za mną chodzisz?”. On mnie mówił: „dytko cię się boi, ty wdowa, jam młodzieniec, jeśli co zrobię, to cię wezmę, jeśli nie zrobię - przepadło". Teraz zrobił śmiech ze mnie czyni wziąć mnie nie chce (CPAHUL 142/1/1: 397 [2 poł. XVII w.]).

Sąd uwierzył jednak Sence, obwinionemu o spłodzenie z nią dziecka, który bronił się wskazując na jej związki z innymi mężczyznami i fakt, że ona „od kilku lat swobodne życie prowadzi”. Jednocześnie jednak sędziowie skazali Senkę na grzywnę za to, „że wiedziawszy o cnocie tej białejgłowy nie warował się onej”. Najpewniej świetnie zdawał sobie sprawę, że może ją uwodzić i mamić małżeństwem bez ryzyka większych konsekwencji (CPAHUL 142/1/1: 397-398).

Wdową była też niejaka Kotka z Rudny Wielkiej (pow. rzeszowski), do której wbrew woli rodziców - „zachodził” i „zabawiał” syn Józefa Micoła. Rzecz działa się już w 1785 r. i należy do stosunkowo nielicznej grupy świadectw, ukazujących pewną zmianę w postrzeganiu seksualnej reputacji kawalerów na wsi polskiej w ostatnich dziesięcioleciach XVIII wieku, kiedy to chyba zadawanie się z kobietami o złej opinii zaczęło przynosić ujmę na honorze domu (choćby sami kawalerowie podchodzili do sprawy inaczej). Kiedy Micołowie dowiedzieli się, że syn poszedł do wdowy Kotki, to pobiegli za nim i zastawszy go u niej, zaczęli bić, a przy okazji dostało się i samej Kotce. Sąd gromadzki zdecydował jednak, że bić Kotki nie mieli prawa (ANK, HGZ 137: 9 [1785]). W sumie nie wiadomo, czy Kotka rzeczywiście stanowiła jakieś zagrożenie dla moralności wsi, czy po prostu jej wdowi status wystawiał ją na podejrzenia. W każdym razie Micołowie wykluczali jakiekolwiek stosunki ich syna z wdową.

Z dokumentów sądowych wyłania się zatem grupa wiejskich kobiet, które angażują się w kolejne związki, ale żaden z nich nie kończy się zamążpójściem, a one 
wręcz w ogóle nie deklarują takiego zamiaru. Oczywiście informacje o nich trafiają do akt dopiero wtedy, gdy dochodzi do spłodzenia dziecka. Takim przy padkiem była Dorota Prykowna z podkrakowskiej wsi Wyciąże, która urodzić miała trójkę nieślubnych dzieci. Jej „seksualna historia” zaczyna się od dziecka spłodzonego w związku z parobkiem Kusiakiem z Krzesławic, który „zrobiwszy mi to poszedł był ze wsi potym”, a dziecko „niewczesne było”. Co ciekawe wiejska plotka głosiła, że prawdziwym sprawcą ciąży miał być ojczym Doroty. Drugie dziecko spłodziła $\mathrm{z}$ „parobkiem Jankiem domowym”, i tak dalej (ANK, Akta m. Krakowa 872: 27-29). Teoretycznie związki Doroty mogły prowadzić do małżeństwa, ale być może ani ona, ani jej kochankowie w ogóle nie brali go pod uwagę. Otwarcie o takim rozwiązaniu mówiła przed sądem Reina Filipionka z państwa suskiego, która domagając się alimentów na nienarodzone jeszcze dziecko od Kazimierza Kołodziejczyka „nie wymawia tego Kazimierzowi Kołodziejczykowi, aby się declarował z nią żenić, tak przed uczynkiem jako i po uczynku, tylko miał mówić jeżeli się co stanie to i ja o tym wiedzieć będę" (AGAD Zbiór Branickich z Suchej 79/98: 478 [1752]). Nie znamy bliższych okoliczności powyższych przypadków, dlatego trudno określić, czym spowodowana była ich odmienność od wiejskiego standardu. Możemy się jednak domyślać, że czasem przyczyną był status mężczyzny, z jakiegoś (zwykle ekonomicznego) powodu niezdolnego do założenia rodziny, a czasem - status kobiety, która albo z wypadła z rynku matrymonialnego wsi, albo może nigdy do niego nawet nie aspirowała, co oczywiście nie znaczyło, że żyła w seksualnej „czystości”.

Na ślad grupy takich kobiet natrafiamy w źródłach historycznych, ale trudno jest ustalić jej wielkość i bliżej scharakteryzować. Można zakładać, że łączy je płodzenie nieślubnego potomstwa (a zwłaszcza recydywa w tym względzie). Niewykluczone, że doświadczenie to było dziedziczne. Trudno uchwycić to statystycznie, ale już Irena Gieysztorowa zwróciła uwagę, że urodzenia nieślubnych dzieci dotyczą często tych samych rodzin, których nazwiska powtarzają się w kolejnych pokoleniach (Gieysztorowa 1981: 434). W badaniach nad wczesnonowożytną Anglią mówi się wręcz o bastardy-prone sub-society (Macfarlane 1980: 75, 81-83; Adair 1996: 68-72). Zjawisko takie występowało być może i na polskiej wsi, a matki nieślubnych dzieci zajmowały tak niskie miejsce w hierarchii społecznej, że trudno było w niej spaść jeszcze niżej, a opuszczenie tej grupy leżało poza zasięgiem zarówno ich możliwości, jak i wyobraźni. Zamążpójście w ich przypadku i tak było niemożliwe, a angażując się w związki z mężczyznami można było liczyć na jakieś gratyfikacje, zaś w przypadku 
urodzenia dziecka - na alimenty. Grupa ta nie była wszakże zamknięta - można było do niej spaść w wyniku życiowych komplikacji takich jak nieudany związek przy jednoczesnej utracie oparcia w rodzinie czy przedłużające się wdowieństwo, powiązane z pauperyzacją.

Owa hipotetyczna grupa kobiet była z pewnością obiektem seksualnego zainteresowania mężczyzn o zbliżonej pozycji społecznej - ekonomicznie upośledzonych, pozbawionych szans na stworzenie i utrzymanie rodziny, niemarzących nawet o własnym gospodarstwie lub zagrodzie, utrzymujących się ze służby i prac dorywczych. Jednak, jak wynika ze źródeł sądowych, partnerami seksualnymi tych kobiet byli również mężczyźni z wiejskiej elity, zarówno żonaci gospodarze, jak i młodzieńcy $\mathrm{z}$ „matrymonialnego rynku” wsi. W istocie chodzi tu o seksualne wykorzystywanie kobiet, które pozostawały upośledzone społecznie i ekonomicznie nawet na tle swojego środowiska. Stałe istnienie takiej grupy na wsi można porównać (oczywiście z zachowaniem wszelki proporcji) do modelu wiktoriańskiego, gdzie wyśrubowane normy obyczajowe wobec kobiet z elit społecznych równoważyło istnienie szerokiego marginesu „kobiet dostępnych” - czy to prostytutek, czy to uważanych za podobnie „niemoralne” kobiet z niższych warstw społecznych (Walkowitz 1980).

Dokładnie to samo środowisko - służące oraz zmarginalizowane społecznie wdowy - oskarżano o przestępstwo dzieciobójstwa. Wprawdzie procesów dzieciobójczyń - jak się wydaje - przeprowadzano w Rzeczypospolitej raczej niewiele, to jednak były one znaczące wśród innych kobiecych przestępstw zagrożonych karą śmierci (Kamler 1986; Karpiński 1995: 328-333). Okrucieństwo kary, jaka spotykała matki, które zabiły swoje dzieci, niewątpliwie pełniła funkcję zastraszającą i nawet nieliczne wykonane wyroki pomagały dyscyplinować całą grupę społeczną, spośród której wywodziły się potencjalne przestępczynie (szerzej: Wiślicz 2014).

Postawione przed sądem wiejskie dzieciobójczynie okazywały się zwykle recydywistkami, które podczas procesu przyznawały się do zabicia nawet kilkorga nieślubnych dzieci. Potwierdzałoby to tezę, że w wiejskiej społeczności wskazywano jako dzieciobójczynie niemal wyłącznie kobiety wyrzucone na społeczno-seksualny margines, a ich surowe ukaranie miało na celu zastraszenie im podobnych. Przykładem jak układało się życie dowiedzionej dzieciobójczyni może być historia Katarzyny Szewcownej, służącej w Gruszowie (pow. myślenicki), która zeznała przed sądem kryminalnym Dobczyc: 
Ja mając dzieci dwoje, które mi się chowają, trzeci raz dopuściłam się popełnienie grzechu takowego z parobkiem Pawłem Krawczykiem. A po tym w kwietną sobotę kazała mi iść gospodyni chust prać [...] prawszy ostatek, uderzyły na mnie bóle, za którem wypadło dziecię ze mnie na lód. A po tym wziąwszy ono dziecię, wrzuciłam go do stawu pod lód, ale do tego nie wiem, czy żywe było czy nie, bom to nagle uczyniła. A po tym poszłam do domu i kazała mi gospodyni wleźć na piec i tam leżałam przez dwa dni (Mikuła 2013: nr 16 [1704]).

Szewcowna pozbyła się zatem dopiero trzeciego nieślubnego dziecka. Być może nie wyobrażała sobie, jak utrzyma jeszcze jedno, a być może bała się utraty pracy (choć gospodyni wykazywała się chyba pewnym zrozumieniem jej sytuacji). Wyraźnie jednak wieś postanowiła się jej pozbyć, zwłaszcza że odnalazło się ciało noworodka. Ostatecznie jednak - dzięki wstawiennictwu posesorki dóbr - nie została skazana na śmierć, tylko na chłostę i wygnanie ze wsi.

Ofiarami systemu względnej swobody seksualnej ludzi stanu wolnego na wsi polskiej stawały się zatem społecznie zmarginalizowane kobiety, których część zapewne dziedziczyła swój status, część zaś znajdowała się w tej pozycji w wyniku niekorzystnych zbiegów okoliczności. Społeczność wiejska budowała ich stygmatyzującą reputację seksualną, żeby uzasadnić ich marginalizację lub eliminację ze wspólnoty. W ten sposób dyskryminacja klasowa krzyżowała się z dyskryminacją ze względu na płeć, a przecięcie tych dwóch zjawisk wywoływało specyficzny system wykluczeń. Kobiety, których dotyczyła ta forma dyskryminacji intersekcjonalnej, padały ofiarą wykorzystania seksualnego, a jednocześnie przerzucano na nie odpowiedzialność za „niemoralne” prowadzenie się, lokując je w kategoriach „nierządnej”, „zawitki”, lub „dzieci tracącej”, czego zwykle nie doświadczały kobiety o stabilnie bezpiecznej pozycji społecznej w chłopskiej gromadzie. Warto zaznaczyć, że sprzymierzeńcem tego zjawiska w wiejskiej obyczajowości w ciągu XVIII wieku stawała się „moralizacja” kultury seksualnej wsi, wdrażana wówczas przed duszpasterstwo katolickie, której adresatem stały się przede wszystkim elity wiejskie, otrzymując ideologiczne uzasadnienie dla seksualnej marginalizacji upośledzonych społecznie kobiet. Proces ten widać w decyzjach sądów gromadzkich, które zaczęły wymierzać kary cielesne kobietom rodzącym nieślubne dzieci, jak również w zacieśnieniu kontroli nad porodami i wzrastającej liczbie procesów o dzieciobójstwo. 


\section{Bibliografia}

\section{Rękopisy}

AGAD - Archiwum Główne Akt Dawnych:

AR (Archiwum Roskie): Dzierżawa Bratkowice 4

ZBS (Zbiór Branickich z Suchej) 79/98: Akta sądowe zamku suskiego. Zbiór rezolucji sądowych w sprawach gmin, należących do państwa suskiego z lat 1677-1760

ZBS (Zbiór Branickich z Suchej) 409/523: Rozmaite papiery i dokumenty sądowe i administracyjne dotyczące poddanych dominium Sucha z lat 1779-1800

ANK - Archiwum Narodowe w Krakowie:

Akta m. Krakowa 872: Prothocolla causarum criminalium officii consularis Crac. 1709-1716

Dep. rkps 100: Księga sądowa kresu muszyńskiego I (1754-1759)

Dep. rkps 101: Księga sądowa kresu muszyńskiego II (1761-1793)

HGZ 137: Xięga do zapisywania dekretów w sprawach gromady wsi Wielkiej Rudny $\mathrm{z}$ nakazu zwierzchności krajowej zrobiona w roku 1782-gim

IT 229h: Księga miasta Nowej Góry [1742-1798]

APP - Archiwum Państwowe w Poznaniu:

Akta m. Słupcy I/5: Księga burmistrzowska i wójtowska Słupcy 1727-1758

APT - Archiwum Państwowe w Toruniu:

ASD (Akta Sądów Dominialnych Dóbr Biskupstwa Chełmińskiego) 1: Księgi ławnicze starogrodzkie 1, 1721-1738

ASD (Akta Sądów Dominialnych Dóbr Biskupstwa Chełmińskiego) 4: Księgi ławnicze starogrodzkie 4: 1747-1753

ASD (Akta Sądów Dominialnych Dóbr Biskupstwa Chełmińskiego) 6: Księgi ławnicze starogrodzkie 6, 1754-1755

BJ - Biblioteka Jagiellońska w Krakowie:

rkps 122: Pisma z w. XVI/XVIII do historii miasteczka Nowej Góry pod Krakowem

BNLUN - Biblioteka Naukowa Lwowskiego Uniwersytetu Narodowego im. Iwana Franki:

rkps 512/III: Ekonomia Samborska 1734

CPAHUL - Centralne Państwowe Archiwum Historyczne Ukrainy we Lwowie:

142/1, sygn. 1: Księga sądowa Czukwi 1586-1680

142/1, sygn. 2: Księga zapisów dekretów i wyroków sądu wiejskiego Czukwi 1638-1680 
142/1, sygn. 4: Księga zapisów dekretów i wyroków sądu wiejskiego Czukwi 1681-1691 142/1, sygn. 8: Księga zapisów dekretów i wyroków sądu wiejskiego Czukwi 1746-1818 856/1, sygn. 172: Akta luźne Ekonomii Samborskiej

\section{Druki}

Adair, R. (1996). Courtship, Illegitimacy and Marriage in Early Modern England. Manchester: Manchester University Press.

Anthias, F. (2013). Intersectional What? Social Divisions, Intersectionality and Levels of Analysis. Ethnicities, 13 (1), 3-19; doi:10.1177/1468796812463547.

Anthias, F. (2014). The Intersections of Class, Gender, Sexuality and 'Race': The Political Economy of Gendered Violence. International Journal of Politics, Culture, and Society, 27, 153-171; doi: 10.1007/s10767-013-9152-9.

Baranowski, B. (1970). Problematyka badań nad mentalnością chłopa pańszczyźnianego na obszarze woj. sieradzkiego i łęczyckiego w XVII i XVIII w. Rocznik Łódzki, 14, 261-276.

Baranowski, B. (1986). Ludzie gościńca w XVII-XVIII w. Łódź: Wydawnictwo Łódzkie.

Barber, J. (1993). "Stolen Goods": The Sexual Harassment of Female Servants in West Wales during the Nineteenth Century. Rural History, 3 (2), 123-136; doi:10.1017/S095679330000025X.

Bilous, N. (2015). Nasyl'stvo nad zhinkamy: siuzhety z mishchans'koho i selians'koho povsiakdennia Volyni XVI-pochatku XVIII st. Socium. Al'manakh social'noï istoriï, 11-12, 135-146. Pozyskano z http://dspace.nbuv.gov.ua/handle/123456789/104599.

Capp, B. (1999). The Double Standard Revisited. Plebeian Women and Male Sexual Reputation in Early Modern England. Past \& Present, 162, 70-100; doi:10.1093/past/162.1.70.

Ciszewski, S. (1927). Żeńska twarz. Kraków: Nakładem Polskiej Akademii Umiejętności.

Gieysztorowa, I. (1981). Les enfants illégitimes dans une paroisse de Pologne aux dix-septième et dixhuitième siècles. W: J. Dupâquier et al.(1981), Marriage and Remarriage in Population of the Past, ss. 429-436. London: Academic Press.

Gowing, L. (2003). Common Bodies. Women, Touch and Power in Seventeenth-Century England. New Haven-London: Yale University Press.

Górna, K. (2001). Narodziny, śluby i zgony na Górnym Śląsku w XVIII wieku. W: H. Suchojad (red.), Wesela, chrzciny i pogrzeby. Kultura życia i śmierci, ss. 33-41. Warszawa: Semper.

Górny, M. (1996). Zawarcie małżeństwa na wsi pałuckiej w XVIII wieku: parafia szaradowska. Genealogia. Studia i Materiały Historyczne, 7, 69-96. 
Guzowski, P. (2011). Agnieszka Sołtysowa z Krościenka Wyżnego. W: P. Guzowski, M. Liedke, M. Ocytkow (red.), Granice i pogranicza. Mikrohistorie i historie życia codziennego, ss. 39-54. Kraków: Avalon.

Guzowski, P. (2012). Wyznaczniki biedy w społeczności chłopskiej w początkach epoki nowożytnej. W: G. Miernik (red.), Bieda w Polsce, ss. 35-44. Kielce: Uniwersytet Jana Kochanowskiego.

Harasymchuk, M. (2015). Spravy pro zgvaltuvannia ı̆ pozbavlennia tsnoty u sudakh Sambirs'koï ekonomii v XVII st. Socium. Al'manakh social'noï istoriï, 11-12, 147-161. Pozyskano z http:// dspace.nbuv.gov.ua/handle/123456789/104600.

Jawor, G. (2010). Zjawisko ubóstwa na wsi polskiej w XV-XVI wieku. (Na przykładzie ziemi lubelskiej). W: L. Kostuch, K. Ryszewska (red.), Zbytek i ubóstwo w starożytności i średniowieczu, ss. 441-451. Kielce: Kieleckie Towarzystwo Naukowe.

Kamler, A. (2005). Chłopi jako pracownicy najemni na wsi małopolskiej w XVI i pierwszej połowie XVII wieku. Warszawa: Firma Księgarska Jacek i Krzysztof Olesiejuk.

Kamler, M. (1986). Dzieciobójstwa w miastach korony w drugiej połowie XVI i pierwszej połowie XVII w. Czasopismo Prawno-Historyczne, 38 (1), 171-184.

Karpiński, A. (1992). Żeńska służba domowa $w$ miastach polskich $w$ drugiej połowie XVII $i w$ XVIII w. W: J. Sztetyłło (red.) Nędza i dostatek na ziemiach polskich od średniowiecza po wiek XX, ss. 41-61. Warszawa: Instytut Historii Kultury Materialnej PAN.

Karpiński, A. (1995). Kobieta w mieście polskim w drugiej połowie XVI i w XVII wieku. Warszawa: Instytut Historii PAN.

Karras, R.M. (1996). Common Women: Prostitution and Sexuality in Medieval England. New York-Oxford: Oxford University Press.

Kołacz-Chmiel, M. (2013). Kobieta w rodzinie i społeczności chłopskiej na pograniczu polsko-ruskim w XV-XVI w. Stan i perspektywy badań. W: J. Hoff, S. Kadrow (red.), Region i regionalizm warcheologii i historii, ss. 184-196. Rzeszów: Wydawnictwo Uniwersytetu Rzeszowskiego.

Kopczyński, M. (1995). Młodość i młodzież na Kujawach w XVIII wieku. Rzecz o czeladzi i służbie w świetle parafialnych spisów mieszkańców z 1791 roku. Przegląd Historyczny, 86, 329-350.

Kowalska-Lewicka, A. (1967). Młodzież wiejska na Podhalu w pierwszej połowie XIX w. (w świetle anonimowej relacji). Łódzkie Studia Etnograficzne, 9, 225-241.

Kowalska-Lewicka, A. (1971). Tradycyjne normy obyczajowe w kontaktach młodzieży na Podhalu. Roczniki Socjologii Wsi, 11, 23-36.

Kracik, J. (1977). Duszpasterstwo parafialne w dekanacie Nowa Góra w pierwszej połowie XVIII wieku. Studia kościelno-historyczne, t. 2. Lublin: Katolicki Uniwersytet Lubelski.

Kuklo, C. (2009). Demografia Rzeczypospolitej przedrozbiorowej. Warszawa: DiG. 
Libera, Z. (1995). Lud ludoznawców: kilka rysów do opisania fizjognomii i postaci ludu naszego czyli, etnograficzna wycieczka po XIX wieku. W: A. Posern-Zieliński (red.), Etnologia polska między ludoznawstwem a antropologia, ss. 138-152. Poznań: Drawa.

Macfarlane, A. (1980). Illegitimacy and illegitimates in English history. W: P. Laslett, K. Oosterveen, R. Smith (red.), Bastardy and its Comparative History: Studies in the history of illegitimacy and marital nonconformism in Britain, France, Germany, Sweden, North America, Jamaica, and Japan, ss. 71-85. Cambridge, Mass.: Harvard University Press.

Mikuła, M.(2013). Księga kryminalna miasta Dobczyc 1699-1737. Kraków: Wydawnictwo Uniwersytetu Jagiellońskiego.

Perzanowski, A. (2009). Odmieńcy. Antropologiczne studium dewiacji. Warszawa: DiG.

Rejman, S. (2006). Urodzenia nieślubne w Krasnem w latach 1786-1863. Przeszłość Demograficzna Polski, 27, 7-38.

Rolle, J. (1869). Materyały do topografii lekarskiej i higieny Podola (Prostytucya). Przegląd Lekarski, 38, 305-307; 39, 313-315; 40, 321.

Ryguła, E.M. (2016). Urodzenia pozamałżeńskie w parafii św. Mikołaja w Ląe w latach 1664-1914. Przeszłość Demograficzna Polski, 38 (2), 7-33; doi:10.18276/pdp.2016.2.38-01.

Scott, J. (2016). Rural Prostitution. W: J. Donnermeyer (red.), The Routledge International Handbook of Rural Criminology, ss. 75-83. London-New York: Routledge.

Sikorska-Kulesza, J.(2004). Zło tolerowane: prostytucja w Królestwie Polskim w XIX wieku. Warszawa: Mada.

Stomma, L. (1975). Rytuał pokładzin w Polsce. Analiza strukturalna, Etnografia Polska, 19 (1), 5164, oai: cyfrowaetnografia.pl:773.

Szymczak, M. (1968). Polskie gwarowe nazwy panny mającej nieślubne dziecko. W: S. Hrabec et al. (red.), Symbolae philologicae in honorem Vitoldi Taszycki. Prace Komisji Językoznawstwa PAN 17, ss. 366-372. Wrocław: Zakład Narodowy im. Ossolińskich Wydawnictwo Polskiej Akademii Nauk.

Taylor, Y. (2010). Complexities and Complications: Intersections of Class and Sexuality. W: Y. Taylor, S. Hines, M.E. Casey (red.), Theorizing Intersectionality and Sexuality, ss. 37-55. Basingstoke: Palgrave Macmillan; doi:10.1057/9780230304093_3.

Thomas, K. (1959). The Double Standard. The Journal of the History of Ideas, 20 (2), 195-216; doi: $10.2307 / 2707819$.

Tomicki, R. (1977). Norma, wzór $i$ wartość w życiu seksualnym tradycyjnych społeczności wiejskich w Polsce. Etnografia Polska, 21 (1), 43-72; oai: cyfrowaetnografia.pl:820. 
Tóth I.G. (1989). Comportements sexuels et contrôle des naissances dans la Transdanubie occidentale au XVIII siècle. Acta Historica Academiae Scientiarum Hungaricae, 35 (1-4), 41-60. Pozyskano z www.jstor.org/stable/42555639.

Ulanowski, B. (1921). Księgi sądowe wiejskie, t. 1-2. Starodawne Prawa Polskiego Pomniki, t. XIXII. Kraków: Nakł. Polskiej Akademii Umiejętności.

Vetulani, A. (1962-1963). Księgi sądowe wiejskie klucza łąckiego. Starodawne Prawa Polskiego Pomniki, seria II, dz. 2, t. 2-3. Wrocław: Zakład Narodowy im. Ossolińskich Wydawnictwo Polskiej Akademii Nauk.

Vinnychenko, O. (2013). „Gvalt ponevol'nyı”. Dvi skarhy pro seksual'nye nasyl'stvo nad seliankamy-piddankamy 1637 i 1648 rokiv. Visnyk L'vivs'koho universytetu. Seriia istorychna 48, 435452. Pozyskano z http://nbuv.gov.ua/UJRN/Vlnu_ist_2013_48_22.

Walker, G. (1996). Expanding the Boundaries of Female Honour in Early Modern England. Transactions of the Royal Historical Society 6, 235-245; doi:10.2307/3679239.

Walkowitz, J.R. (1980). Prostitution and Victorian Society: Women, Class and the State. Cambridge: Cambridge University Press.

Wężowicz-Ziółkowska, D. (1991a). Miłość ludowa. Wzory miłości w polskiej pieśni ludowej XVIIIXIX w. Wrocław: Polskie Towarzystwo Ludoznawcze.

Wężowicz-Ziółkowska, D. (1991b). Seksualizm ludowy w świetle obscenicznej pieśni ludowej. W: J. Kolbuszewski, T. Żabski (red.), Literatura i Kultura Popularna I, ss. 137-167. Wrocław: Wydawnictwo Uniwersytetu Wrocławskiego.

Wężowicz-Ziółkowska, D. (2008). Modele polskiej seksualności ludowej (wraz z postscriptum). Postscriptum Polonistyczne, 2 (2), 71-95.

Wiener, C.Z. (1975). Sex Roles and Crime in Late Elizabethan Hertfordshire. Journal of Social History, 8 (4), 38-60; doi:10.1353/jsh/8.4.38.

Wiślicz, T. (2012). Upodobanie: Małżeństwo i związi nieformalne na wsi polskiej XVII-XVIII wieku. Wyobrażenia społeczne ijednostkowe doświadczenia. Wrocław: Chronicon.

Wiślicz, T. (2014). Dzieciobójstwo jako narzędzie polityki reprodukcyjnej w Rzeczypospolitej XVIIXVIII wieku. W: B. Popiołek, A. Chłosta-Sikorska, M. Gadocha (red.), W kręgu rodziny epok dawnych. Dzieciństwo, ss. 141-151. Warszawa: DiG.

Wiślicz, T. (2017). Dialectics of virginity. Controlling the morals of youth in the early modern Polish countryside. W: S. Lidman, T. Linkinen, M. Heinonen, M. Kaartinen (red.), Framing Premodern Desires: Sexual Ideas, Attitudes, and Practices in Europe, ss. 83-102. Amsterdam: Amsterdam University Press. Pozyskano z http://www.jstor.org/stable/j.cttlv2xsm3.8. 
Wyczański, A. (2005). Zły los Zosi Kotówny (1544): (mikrohistoria). Odrodzenie i Reformacja w Polsce 49, 105-112.

Wyżga M. (2010). Urodzenia pozamałżeńskie w podkrakowskiej parafii Raciborowice w XVII-XVIII wieku w świetle ksiąg metrykalnych. Przeszłość Demograficzna Polski, 29, 157-171. 